be similar in the spring. 2. Goat kids born in the spring ought to be castrated at the age of $2-3$ months. 3. It may be recommended that selection for growth rate should be based on data corrected for seasonal effects.

Key words : Kids, Yaez, growth.

\title{
Relative growth rate of intermuscular adipose tissue in kids of the Granadina breed
}

\author{
M. R. SANZ SAMPELAYO, F.J. MUÑOZ HERNÁNDEZ *, L. LARA, \\ Francisca GIL EXTREMERA, J. BOZA \\ Departamento de Fisiología Animal, Estación Experimental del Zaidín (C.S.I.C.), \\ 18008 Granada (Spain) \\ * From Veterinary Sciences Faculty, Austral University (Chile).
}

Two experiments were carried out with the aim of determining the particular relative growth rate of intermuscular adipose tissue in Granadina kids. The experimental period was milk feeding, from birth until 30 days of age. The animals were fed with goat milk or a milk replacer at two different levels of metabolisable energy intake. Eight animals were used in each experiment. They were 1 or 2 to 15 days old in the first experiment and up to 30 days old in the second one. Two animals were fed goat milk or a milk replacer at a rate corresponding to 1.86 or 2.48 times the level of metabolisable energy supply for maintenance $(1.86 \mathrm{M}$ or $2.48 \mathrm{M})$, i.e. $103 \mathrm{Kcal} / \mathrm{Kg}^{0.75}$ day.

A group of five animals was slaughtered at birth. The day after each experiment was finished, all experiment animals were slaughtered. The left side of each carcass was cooled at $4{ }^{\circ} \mathrm{C}$ and divided into seven cuts : leg, rib, loin, shoulder, breast, neck and tail. Each cut, except the tail, was separated by dissection into muscle, fat, bone and waste and each tissue quantity was weighed. For each kind of milk and intake level, the allometric coefficient of the intermuscular adipose tissue of the carcass and each cut was calculated according to carcass or cut weight.

The mean carcass weight of the animals slaughtered at 30 days of age was $2,850 \pm 229.3 \mathrm{~g}$. The allometric coefficients for each kind of milk and level of intake exceeded 1.0, indicating that the fat proportions increased during the period of growth. Beside the two involved variables, these values were : $1.71 \pm 0.07,1.76 \pm 0.06,1.71 \pm 0.07,1.53 \pm 0.06,1.88 \pm 0.04,1.95 \pm 0.01$ and $1.60 \pm 0.14$ for carcass, leg, rib, loin, shoulder, breast and neck, respectively. The cuts that normally showed the highest relative growth rate exhibited the most rapid development of intermuscular adipose tissue. The type of milk had no significant effect on the relative growth of the intermuscular adipose tissue. With the high level of intake $(2.48 \mathrm{M})$ the allometric coefficients were higher than those reached under the medium level $(1.86 \mathrm{M})$, being statistically different for the loin and neck $(P<0.05)$. For the leg these data were different at $P<0.10$.

The present study evidenced the effects of the type of milk and level of intake on the development of the intermuscular adipose tissue in the kid.

The intermuscular adipose tissue of Granadina kid carcass appears to have a normal relative growth similar to that of most mammals.

Key words: Adipose tissue, growth, kid, Granadina. 